\title{
Research on Reform Requirements to and Reform Path of Power Grid Enterprise' Collective Assets
}

\author{
Sun Lichun ${ }^{1, a^{*}}$, Zhang Hualei ${ }^{2, b}$

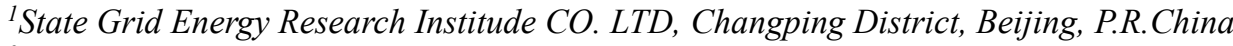 \\ ${ }^{2}$ State Grid Energy Research Institude CO. LTD, Changping District, Beijing, P.R.China \\ $a^{*}$ sunlichun@sgeri.sgcc.com.cn \\ ${ }^{b}$ zhanghualei@sgeri.sgcc.com.cn
}

\begin{abstract}
In 2019, the State-owned Assets Supervision and Administration Commission issued the "Notice on Accelerating the Relevant the Reform of the Central Enterprises' Factory-owned Collective Enterprises" (SASAC Reform [2019] No. 20) to make further arrangements. The collective assets of power grid enterprises are faced with the multiple requirements of the reform of factory-owned collective enterprises, the reform of state-owned assets and state-owned enterprises, and the reform of the electric power system. Based on the analysis of the latest reform requirements, this study clarifies the the main problems existing in the reform and development of power grid enterprise' collective assets and related enterprises, and the uniqueness of the deepening reform in terms of basic conditions and constraints, thereby proposing multiple considerations for goal of deepening reform, and the path of thinking in the near and long-term reform.
\end{abstract}

Keywords: power grid enterprise, collective assets, reform requirements, reform path

\section{INTRODUCTION}

In April 2011, the State Council issued the "Guiding Opinions on Carrying out the Reform of Factory-Managed Large Collectives Nationwide" (Guobanfa [2011] No. 18) on the basis of the pilot reform of the Northeast China, requesting the promotion of factory-operated large collectives nationwide Reform work. Since then, the SASAC, the Ministry of Human Resources and Social Security, the Ministry of Finance and other ministries have successively issued a series of guidelines and normative documents to further refine and clarify issues such as personnel placement, labor relationship handling, asset evaluation, and asset disposal in the reform . In 2016, the State Council promulgated the "Working Plan for Accelerating the Diversion of State-owned Enterprises from Social Functions and Solving Historical Issues" (Guo Fa [2016] No. 19), and in 2019, the SASAC issued the "Notice on Accelerating the Relevant the Reform of the Central Enterprises ' Factory-owned Collective Enterprises" (SASAC Reform [2019] No. 20), further arrangements are made for the collective reform of the factory. In recent years, power grid companies have gradually carried out work such as asset cleanup and capital verification, corporate disposal, and personnel placement, and have achieved remarkable results. The concentration of business, assets, management, and standardized operations have been significantly improved. As of the end of 2019 , about $90 \%$ of the surviving firms are corporative enterprises. Under the new reform situation, scientificly planning deepening reform path is quite urgent and significant.

\section{REFORM SITUATION AND REFORM REQUIREMENTS}

The reform of the power grid enterprises' collective assets and the disposal of related enterprises are affected by the reform requirements of factory-owned collective enterprises, the reform of state-owned assets and enterprises, and the reform of electric power system.

\subsection{The Main Policy Requirements of the Reform of Factory-owned Collective Enterprises}

Comprehensive analysis of the three main policy documents, "Guiding Opinions on Carrying out the Reform of FactoryManaged Large Collectives Nationwide" (Guobanfa [2011] No. 18), "Working Plan for Accelerating the Diversion of State-owned Enterprises from Social Functions and Solving Historical Issues" (Guo Fa [2016] No. 19), and "Notice on Accelerating the Relevant the Reform of the Central Enterprises' Factory-owned Collective Enterprises" (SASAC Reform [2019] No. 20) shows that:

(1) The original intention of the reform was to relieve pressure on the state-owned enterprises, properly relocate the employees affected by the operating difficulties, and promote the state-owned enterprises to concentrate 
resources to strengthen their main businesses and compete fairly with other market entities.

(2) The goal of the reform of factory-owned collective enterprises is to completely separate from host state-owned enterprises, and become independent legal entities and market entities with clear property rights, market-oriented, and self-financing. "Clear property rights, market-oriented, self-financing" and "independent legal entities and market entities" is the meaning and standard of "complete separation".

(3) Maintaining stability and properly distributing and resettling employees are important constraints for implementing the reform.

(4) The disposal methods of factory-owned enterprises and the assets include but not limited to restructuring, joint venture, sale, bankruptcy, etc.

(5) The remaining net assets after payment of reform costs such as employee economic compensation are clearly owned by host state-owned enterprises.

(6) The reform should be basically completed in 2020 .

\subsection{Impacts of the Reform of State-owned Assets and Enterprises}

Since the host enterprises are state-owned, the collective assets that have completed clearance and have not been disposed of should be in compliance with regulatory requirements to state-owned assets and enterprises. ${ }^{[1]}$ Since the Third Plenary Session of the Eighteenth Central Committee of the Party, there has formed a " $1+\mathrm{N} "$ policy system to accelerate the in-depth advancement of the reform of state-owned assets and enterprises. The impacts of major reform trends on collective assets and related enterprises include:

(1) The reform of the authorized operating system and the supervision of state-owned assets with a focus on capital management provide guidance for power grid enterprises to optimize the supervision of collective assets and related enterprises. It is necessary to further improve the classification and supervision structure of collective assets and strengthen related enterprises' principle position on the market. $^{[2]}$

(2) To strengthen the supervision of state-owned assets requires strengthening the compliance management of relevant enterprises, further straightening out the relationship between related enterprises and the main business of the power grid, strengthening the top-level design, clarifying the principles of collective capital supervision and layout strategy, etc., effectively preventing the loss of collective assets, and improving operational efficiency and effectiveness.

(3) Improving the corporate governance structure requires further perfecting the authority-responsibility relationship between the host enterprises, collective assets-related enterprises and other governance entities, and implementing and maintaining the exercise of rights by the company's board of directors.

(4) The policies and regulations on mixed-ownership reform provides guidance for the steadily and orderly promotion of collective assets and related enterprises to promote mixedownership reform and participate in the formation of mixedownership economy。

\subsection{Impacts of the Reform of Electric Power System}

In 2015, the Central Committee of the Communist Party of China and the State Council issued "Several Opinions on Further Deepening the Reform of the Electric Power System" (Zhongfa [2015] No. 9), which clearly stipulated the overall objectives, basic principles and key tasks of the current round of reform of electric power system. The new round of reform is based on the further improvement of the separation of government and enterprises, separation of plants and network, and separation of main and auxiliary businesses, in accordance with the institutional framework of controlling the middle and opening up both ends, and proceeding in an orderly manner. The impacts of reform of electric power system on the collective assets of power grid enterprises and the disposal of related enterprises mainly include:

(1) The separation of main and auxiliary businesses requires power grid enterprises to accelerate research and promote the separation, and promote effective separation of power design, repair, construction and other units from power grid enterprises.

(2) The market-oriented reform requirements have intensified competition in the fields of incremental power distribution, electricity sales, and value-added services. Under the framework of the market-based system and mechanism, collective asset-related companies need to strengthen the abilities in power grid operation guarantee, customer service guarantee, and expanding innovative business.

(3) Affected by the supervision and review of transmission and distribution prices, power grid companies need to further standardize the transaction mechanism and management process between the host enterprises and the enterprises related to collective assets to avoid the risks of violations and connected transactions; at the same time, it's necessary for related enterprises to strengthen cost management and actively expand external market business.

\section{DEVELOPMENT CHALLENGES TO THE RELATED ENTERPRISES}

Faced with the new situation and new requirements, the collective assets of power grid enterprises and related enterprises face greater challenges in terms of supervision and management, corporate governance, market-oriented operating mechanisms, and business development. 


\subsection{Various Aspects of Supervision Have Become Stricter}

Several government departments require the regulation of connected transactions between related enterprises and host enterprises, and to accelerate deepening reform; local governments and public opinion pay much attention to the safety of related enterprises and put their safety in production as a measure of the corporate social responsibility of the power grid enterprises; the central and local governments vigorously promote the optimization of the business environment, and put forward higher standards and fairness requirements for the related enterprises to undertake the business of power supply companies; industry supervision in the fields of power construction and installation is increasing strict, higher requirements have been put forward to regulate the operation of the related enterprises and power supply companies' active fulfilling responsibilities. On the whole, the regulatory situation requires power grid enterprises to strengthen the supervision of collective assets and related companies, and speed up the improvement of the supervision system covering key areas such as investment, capital, projects, and safety.

\subsection{Corporate Governance System and Management-Control Mode Need to Be Optimized}

Corporate governance structure of the platform companies in various provinces still needs to be improved. There exists the situation in some platform companies that the chairman also serve as the general manager, and senior management personnel also serve as supervisors, which is incompatible with the principle of power balance; the authority-responsibility relationship between host enterprises, platform companies, and subordinate companies needs to be further clarified. The physical operation and management functions of platform companies need to be strengthened. For example, platform companies' assessment of their subordinate enterprises has become a mere formality, management effectiveness of performance feedback, incentive fulfillment, and talent development are greatly compromised. At present, the supervision and management mode for collective assets-related enterprises doesn't adapt to the requirements of legal entity autonomy and corporate governance structure, neither intensive management-control adapts to the market-oriented competition. It is necessary to further clarify the rights and responsibilities of each subject, and optimize platform companies' management-control system for subordinate enterprises.

\subsection{Capabilities and Mechanisms of Operation and Management Need to Be Optimized}

The management foundation of the related enterprises is still comparatively weak on the whole, and the market-oriented operation mechanism has not been established, which is not conducive to compacting the responsibility of the entities and stimulating the vitality of enterprises. The operation and management of enterprises in some regions are comparatively extensive, and the internal control mechanism is not yet perfect. It is necessary to further strengthen the team building, improve the mechanism and process, and improve the level of management capabilities. In some regions and individual units, managing enterprises in accordance with the law and regulating connected transactions is not effective enough, relevant work has not been promoted properly, and violations of discipline and regulations have been exposed. The interest distribution and development channels of various types of employees in the enterprises are relatively solid. It is difficult to attract excellent talents and motivate key employees, and seriously restricts the construction of the company's core capabilities. Market-oriented employment mechanism, evaluation and incentive mechanism need to be optimized.

\subsection{Pressure and Motivation of Business Innovation Need to Be Improved}

There exist a close relationship between the collectiveassets-related enterprises and host enterprises. On the one hand, they support each other and develop in a coordinated manner. On the other hand, a large proportion of their profit revenue comes from power supply companies, and construction design business revenue accounts for too much, business development may be greatly affected by the reform of separation of main and auxiliary businesses. In addition, although the related enterprises cooperate with power supply companies to carry out innovation in power supply service methods, improve quality and efficiency, and help improve customer service levels, they still lack unique business model, which weak the ability of market-oriented, healthy and sustainable development. ${ }^{[3]}$

\section{UNIQUENESS OF REFORM AND DISPOSAL OF POWER GRID ENTERPRISES' COLLECTIVE ASSETS}

After years of reform and development, the collective assets and related enterprises of the power grid enterprises are very different from the initial stage of the reform, and other central enterprises and state-owned enterprises, whose collective assets' scale is much smaller. The reform and disposal of power grid enterprises' collective assets has its own unique characteristics in terms of basic conditions and constraints:

(1) The operating conditions of related enterprises are generally good, and there is a significant difference from the background of the document issued by Guobanfa No. 18 for enterprises with operating difficulties and for host enterprises to release the burden.

(2) Related enterprises play a functional value in power grid security, local social economy, etc., which is significantly 
different from the problems which the reform need to solve, that factory-owned collective enterprises hinder the reform and development of host enterprises and there exists a risk of social harmony and stability.

(3) The vast majority of enterprises have been transformed into corporate enterprises with clear property rights and initially established a modern enterprise system and corporate governance system, which is significantly different from collective-owned enterprises.

(4) The total number of employees in related enterprises is large. The employees' identities are diverse, and their demands are diverse. If the impact of deepening reform is too great, there will be a high risk of stability.

(5) The related enterprises have a wide geographical distribution, uneven development, varying degrees of marketization, and certain remaining problems, all of which pose severe challenges to the applicability and scientificity of deepening reform methods.

\section{CONCLUTION}

The comprehensive analysis shows that multiple goals need to be taken into account in the process of deepening reform: maintaining a stable workforce, promoting the effective separation of related enterprises and host enterprises, ensuring the safe production of power grids, realizing the preservation and appreciation of assets, promoting the healthy and sustainable development of surviving enterprises, while complying with requirements of supervision, audit, and inspection etc. ${ }^{[4]}$ It is necessary to properly handle the relationship between adapting to supervision, supporting the power grid, reform, and development, as well as making proper arrangements for deepening reform tasks, and achieving multiple reform goals in stages. ${ }^{[5]}$

In the near future, we should focus on the main contradictions to ensure that the stability of the workforce and the safe production of the power grid are guaranteed under the premise of meeting the regulatory requirements. We need to promote the effective separation of related enterprises and host enterprises through innovative institutional mechanisms, and deepening market-oriented operations. On the while, we need to speed up the disposal of collective-owned enterprises, effectively solve the problems left over by history to make significant progress in work, laying a good foundation for further reform and development.

In the long run, we should focus on thoroughly solving the "legacy problems", while protecting the rights and interests of the country, enterprises and employees in accordance with laws and regulations, without affecting the safety and stability of the power grid, and solving the problems of the ultimate ownership of collective assets and the operation and development model of the surviving enterprises. We should closely track the latest deployment requirements for the reform of state-owned assets and enterprises, and the reform of the electric power system, as well as strengthen interaction and coordination with regulators, to scientifically formulate a timetable and roadmap for deepening reform, and further innovate institutional mechanisms and reform methods. When the policies and environmental conditions are available, the final property right of collective assets shall be confirmed as state-owned, and the independent operation, healthy and sustainable development of the surviving enterprise shall be realized finally.

\section{ACKNOWLEDGMENT}

This work was supported by the project "Research on the development theory and evaluation system of 'Becoming stronger, better and bigger' under the background of state-owned capital and state-owned enterprise reform" of State Grid Co. LTD.

\section{REFERENCES}

[1] Yin X.D., Research on the Regulatory Legal System of Enterprises' State-owned Assets Supervision [D]. Liaoning University, 2010.

[2] Chu Y.J., Research on the Reform of Collective Enterprises' Property Rights System [D]. Wuhan University of Technology, 2007.

[3] $\mathrm{Hu}$ F. (2007) Reform and International competitiveness of Market-oriented Enterprises: Theoretical and Empirical Research on the Reform of Contemporary Japanese Enterprises. Renmin Press, Beijing.

[4] Pan T.P., The reform of Factory-owned Collective Enterprises and the Reconstruction of Labor relations: Taking Electric Power Collective Enterprise as an Example [J]. China Labor, 2012, (7): 14-16.

[5] Ji M.L., Li G.H., Research on the Difficulties and Countermeasures in the Reform of Factory-owned Collective Enterprises $[\mathrm{J}]$. China Collective Economy, 2007, (11):41-42. 